\title{
ALIENAÇÃO PARENTAL E SUAS CONSEQUÊNCIAS JURÍDICAS
}

\author{
Suellen Fernanda Portela ${ }^{1}$ \\ Denise Passos da Costa Plínio ${ }^{2}$ \\ Mauricio Martins Alves ${ }^{3}$
}

Resumo: O objetivo deste trabalho é analisar as consequências jurídicas advindas com a prática da Alienação Parental. A lei 12.318/2010 foi criada com o fim de garantir à criança e ao adolescente um desenvolvimento saudável em uma família devidamente estruturada, prevendo "punições" àquele que abusar do seu poder familiar ou influência sobre a criança, implantando falsas memórias sobre qualquer dos genitores, vindo a praticar com isso, o cada dia mais conhecido ato de Alienação Parental. O texto conduz a uma análise das consequências trazidas nos incisos do artigo $6^{\circ}$ dessa lei como forma de conscientização da gravidade desse ato e como a lei se incumbe de apresentar meios inibidores para o mesmo.

Palavras-chave: Alienação Parental; Consequências jurídicas; Família.

\footnotetext{
${ }^{1}$ Direito/Universidade do Vale do Paraíba-Univap, Brasil. E-mail: suellen_fernanda_@hotmail.com.

2 Direito/Universidade do Vale do Paraíba-Univap, Brasil. E-mail: dplinio@univap.br.

${ }^{3}$ Direito/Universidade do Vale do Paraíba-Univap, Brasil. E-mail: mmalves@univap.br.
} 